МРНТИ 20.01.45

УДК 618.005

https://doi.org/10.51889/2020-2.1728-7901.33

\author{
M. Ерекешева ${ }^{l}$, А. Бедер ${ }^{l}$ \\ ${ }^{1}$ Қ. Жұбанов атындавы Ақтөөбе өңірлік мемлекеттік университеті, Ақтөбе к., Қазақстан
}

ПРОГРАММАЛАУДЫ ОҚЫТУҒА АРНАЛҒАН ҚОСЫМША ҚҰРУ

\begin{abstract}
Аңцдатпа
Заманауи студенттердің көпшілігі оқу үрдісіне мобильді технологияларды қолдануға дайын және мобильді құрылғылар мен технологиялардың әлеуетін барынша тиімді пайдалану үшін жаңа мүмкіндіктерді қарастыру қажеттілігін түсінеді. Бұл міндетті шешуде жоғары оқу орындарының оқу үрдісіне мобильдік оқыту стратегиясын, нысандары мен әдістерін енгізуді талап етеді. Қазіргі уақытта мобильді қосымшаларды әзірлеу ақпараттық технологиялар саласындағы ең танымал міндеттердің бірі болып табылады. Енді қосымшалар бірнеше көздерден алынған ақпаратқа талдау жасай алады және қолданушыға шешім қабылдауға, процестерді бақылауға және басқа да маңызды міндеттерді шешуге көмектеседі. Бұл өз кезегінде бизнес-процестерді оңтайландыруға, қабылданатын шешімдердің өнімділігі мен тиімділігін арттыруға ықпал етеді.

Мақалада программалауға үйретуші мобильді қосымшаны жобалау және құру процесі, программалық жабдықтары, қосымшаның мазмұны, функционалдық мүмкіндіктері сипатталған.

Түйін сөздер: программалау, мультимедиялық оқу құралдары, видеодәрістер, оқу порталы, Webқосымша, электронды оқыту жүйесі, қолданушы интерфейсі, мобильді қосымша, операциялық жүйе

\author{
Аннотация \\ М. Ерекешева ${ }^{1}$, A. Бедер ${ }^{1}$ \\ ${ }^{1}$ Актюбинский региональный государственный университет им.К.Жубанова, г.Актобе, Казахстан
} РАЗРАБОТКА ПРИЛОЖЕНИЙ ДЛЯ ОБУЧЕНИЯ ПРОГРАММИРОВАНИЮ
\end{abstract}

Большинство современных студентов готовы использовать мобильные технологии в учебном процессе и осознают необходимость рассмотрения новых возможностей для наилучшего использования потенциала мобильных устройств и технологий. Решение этой задачи требует внедрения мобильных образовательных стратегий, форм и методов в учебный процесс вузов. В настоящее время разработка мобильных приложений является одной из самых популярных задач в области информационных технологий. Теперь приложения могут проанализировать информацию, полученную из нескольких источников, и помочь пользователю принимать решения, контролировать процессы и решать другие важные задачи. Это, в свою очередь, способствует оптимизации бизнес-процессов, повышению производительности и эффективности принимаемых решений. В статье описан процесс проектирования и создания мобильного приложения для обучения программированию, программное обеспечение, контент и функцианольные возможности приложения.

Ключевые слова: программирование, мультимедийные учебники, видеолекции, обучающий портал, Webприложение, система электронного обучения, пользовательский интерфейс, мобильное приложение, операционная система

\title{
Abstract \\ DEVELOPMENT OF APPLICATIONS FOR LEARNING PROGRAMMING
}

Yerekesheva $M^{l}$., Beder A. ${ }^{l}$

${ }^{1}$ K. Zhubanov Aktobe regional state University, Aktobe, Kazakhstan

Most modern students are ready to use mobile technology in the learning process, and understand the need to consider new opportunities for the best use of the potential of mobile devices and technologies. The solution of this task requires the introduction of mobile learning strategies, forms and methods in the educational process of universities. Currently, the development of mobile applications is one of the most popular tasks in the field of information technology. Applications can now analyze information from multiple sources and help the user make decisions, control processes, and solve other important tasks. This, in turn, helps to optimize business processes, increase productivity and efficiency of decisions. The article describes the process of designing and building a mobile application for teaching programming, software, content, and functionality.

Keywords: programming, multimedia textbooks, video lectures, training portal, web application, e-learning system, user interface, mobile application, operating system

Ақпараттық ресурстар, жүйелер және технологиялар - адамның қазіргі өмір сүруінің ажырамас, қарқынды дамып келе жатқан элементтері. Н.М. Куляшова, И.А. Карпюк және С.А. Дроздовтың еңбектерінде мобильді қосымшаларды құруда сапалы серпіліс үлкен сенсорлық экрандары бар 
мобильді құрылғылардың өндірісінен бастау алғандығын, бұл жаңа деңгейдегі мобильді қосымшаларды жасауға мүмкіндік беретінін көрсеткен. Көптеген программалаушылар кәсіби қызметтің жаңа бағыттарын игеріп, нарықтық үрдістерге бейімделе бастады [1]. Н.В. Пантилейкин өз еңбегінде мобильді қосымшаны - белгілі бір іс-әрекеттерді орындауға мүмкіндік беретін қандай да бір функционалы бар, белгілі бір платформада орнатылған телефон үшін арнайы бағдарлама деп анықтап, оның қолданылу аясына сәйкес түрлерін ажыратқан [2].

Оқытудың қазіргі әдістемелерін сапалы жаңғырту және жаңарту оқушыларды оқытудың қазіргі заманғы білім беру процесіне қажет. Мобильді программалық жабдықты пайдалану оқытушылардың ғана емес, студенттердің де уәждемесін арттырудың тиімді және қолжетімді тәсілдерінің бірі. Мобильді оқыту - дәстүрлі оқытуды алмастырмайды, бірақ ол жоғары мектептегі оқыту процесіне қосымша ретінде және аралас оқыту компоненті ретінде пайдаланылуы мүмкін деп айтуға болады. Мобильді оқытуды белсенді қолдану компьютерлерді портативті гаджеттерге ауыстыруды мақсат етпейді, қайта білім беру үдерісін қызықты әрі өзекті әдістермен кеңейтеді және толықтырады.

Мобильді құрылғыларға арналған, арнайы бейімделген оқу материалдары бойынша, бұл әдіс арнайы түрде қалыптастырылған электрондық оқулықтарды және оқыту файлдарын пайдалануды білдіреді, оқу материалдары мобильді платформаларға арналып арнайы жобаланады. Мобильді құрылғыларды оқыту құралы ретінде қолданудың осы тәсілі - оқушылардың мобильдік құрылғыларында оқу тапсырмаларын қарау және орындау үшін бейімделген және қалыптасқан мамандандырылған оқыту материалдарын қолдану болып табылады. В.А.Куклев мобильді оқытуды «Арнайы бағдарламалық қамтамасыз ету пайдаланылатын және пәнаралық және модульдік тәсілдерге негізделген нақты уақыт пен орынға байланысы жоқ мобильді құрылғылар мен құрылғылардың көмегімен электрондық оқыту» деп қарастырады [3].

Студенттерге мобильді құрылғыға арнайы программалар орнатуға және бақылау үшін қажетті тақырыптар бойынша оқу материалдарын жүктеуге мүмкіндік беріледі, мысалы - тестілер, сондай-ақ бақылау кезеңдерінен сәтті өту үшін қажетті барлық қосымша оқу материалдары да болады. Оқу материалдарын әзірлеудің заманауи құралдары осындай бағдарламалық кешендер мен оқу материалдарын жобалауға мүмкіндік береді, ал оқу материалдарында әртүрлі сызбаларды, кестелерді, формулаларды және мультимедиа материалдарын орналастыру мүмкіндігі кез келген оқылатын пәнге қолданылатын және әмбебап оқу материалдарын жасауға мүмкіндік береді.

Мобильді құрылғыларға арналған жобаларды техникалық іске асырудың екі бағыты бар: мобильді web-сайт және мобильді қосымша.

1. Мобильді web-сайт деп мобильді құрылғыда көру және жұмыс істеу үшін бейімделген WEB сайт саналады. Сайт JavaScript, HTML5, және API браузерлерді пайдалана отырып, интерактивті компоненттерді қамтуы мүмкін. Бұл жағдайда мұндай сайт web-қосымша деп аталады.

2. Мобильді қосымшалар - мобильді құрылғыларға орнатылатын нақты мобильді платформа (iOS, Android, Windows Phone) бойынша арнайы әзірленген бағдарлама.

Ең алдымен, "мобильді қосымша" ұғымын анықтау қажет. "Мобильді қосымша" - бұл нақты мобильді платформа (iOS, Android, Windows Phone) үшін арнайы әзірленген қосымша. Көптеген мобильді қосымшалар алдын-ала орнатылған болады немесе App Store, Google Play Market, Windows Phone Store, Яндекс.Store сияқты қосымшалардың онлайн дүкендерінен тегін немесе ақылы жүктелуі мүмкін. Мобильді қосымшалар мобильді құрылғыларды пайдаланушылардың өмірін жеңілдетуге, сондай-ақ оны оңтайландыруға бағытталған .

Мобильді қосымша веб-сайттың ұялы нұсқасымен салыстырғанда бірқатар артықшылықтарға ие:

- ыңғайлы және түсінікті интерфейс;

- онлайн бағдарламалары;

- пайдаланушымен тұрақты байланыс;

- геолокация;

- қолданушы туралы деректерді дәл жинақтау.

Білім беруші мобильді қосымша қолданушыларға:

- дидактикалық материалды барынша ыңғайлы және көрнекі етіп беру;

- оқуға деген қызығушылық және білімдегі олқылықтарды жоюға;

- оку материалына шолу жасау және талдау жасау;

- жауаптарды таңдау арқылы тестілеуден өту;

- кез келген ыңғайлы уақытта білім берумен айналысу;

- біліктілігі деңгейін арттыру; 
• оқытушылардан жедел кері байланыс алу;

- оқыту материалдарына қол жеткізу және т.б. мүмкіндік береді.

Қазіргі заманғы технологиялар біздің өмірімізге терең енуде және қазір смартфонсыз немесе басқа да көпфункционалды гаджетсіз адамды табу қиынға соғады. Олардың жұмыс істеуі операциялық жүйесіз мүмкін емес және қазіргі уақытта Android операциялық жүйесі (ОЖ) ең танымал болып табылады. Ақпараттық технологиялар нарығын талдауға маманданған америкалық Gartner компаниясының деректері бойынша Android үлесі 2017 жылдың 4 тоқсанында 85,9\% құрады. Әлем бойынша осы операциялық жүйенің басқаруындағы 1,32 млрд. құрылғы сатылды [4]. Android салыстырмалы түрде жаңа операциялық жүйе болып табылады, бірақ қысқа уақыт ішінде ол мобильді құрылғылар нарығында өте танымал болды. Android платформасының негізгі артықшылықтарының бірі - оның ашықтығы. Android операциялық жүйесі ашық бастапқы код негізінде құрылған және еркін таралған. Бұл әзірлеушілерге бастапқы кодқа қол жеткізуге және қолданбалардың қасиеттері мен функцияларының қалай жүзеге асырылғанын түсінуге мүмкіндік береді. Кез келген пайдаланушы осы операциялық жүйені жетілдіруге қатыса алады.Программалық жабдықтар ішінен Android платформасы таңдалды.

Ал программалауды үйретуге арналған мобильді қосымшаның мақсатты аудиториясын анықтау үшін, осы «Программалау» пәнін кім оқиды?»,-деген сұрақтың жауабын анықтадық, олар:

- Мектеп жасындағы оқушылар;

- жОО-да білім алып жүрген студенттер;

- «Информатика» пәнінің мұғалімдері;

- Өз бетімен программалауды үйренгісі келетін қолданушылар (IT саласында қызмет жасаушылар, мүмкіндігі шектеулі адамдар, т.б.)

Сайып келгенде, қосымшаны пайдалануда қолданушыларға қатысты шектеулер жоқ. Ақпараттың ой-өрісін кеңейтетін білім беруге еркін қол жеткізу - салауатты қоғамның негізгі шарттарының бірі.

Қосымшалардың барлық талаптары функцияларға бөлінеді - функциональды және функционалды емес. Функционалдық талаптар қолданушылар өз міндеттерін орындай алуы үшін әзірлеушілер жасауы тиіс жүйенің функционалдығын анықтайды. Функционалды емес талаптар жүйемен жұмыс істеу кезінде пайдаланушы үшін маңызды қосымшаның сипаттамасын білдіреді.

«B2A Learning» мобильді қосымшасының функционалдық мүмкіндіктерін мына ретпен сипаттауға болады:

1) Қолданушы тіркеледі;

2) Оқитын пәнді таңдайды;

3) Таңдалған пәнге сәйкес бейне сабақтарды қарайды;

4) Қажет болған жағдайда бейне сабақтың мәтіндік нұсқасын қарайды ;

5) Сәйкес тақырып бойынша практикалық тапсырмаларды орындайды;

6) Онлайн Compiler көмегімен құрған программаларын орындауға жібереді, тексереді;

Әр тақырып соңында, бекіту мақсатында сұрақтарға жауап береді. Мобильді қосымшаның графикалық интерфейсінің дизайнын жобалау кезеңінде басты мақсат анықталды - пайдаланушыға жақсы байланыс жасау тәсілін қамтамасыз ету.

Осы аталған талаптарға сәйкес жасалған «B2A Learning» мобильді қосымшасының интерфейсі 1 суретте көрсетілген.

Қосымшаларды әзірлеуден бастамас бұрын, оның қандай түрі мен көлемін сақтау керек екенін анықтау қажет. Android операциялық жүйесінде деректерді сақтаудың бірнеше жолы бар:

1. Shared Preferences.

2. SQLite деректер қоры.

3. Ішкі немесе сыртқы жадты пайдалану арқылы қарапайым файлдар.

Аталған тәсілдердің әрқайсысының өз артықшылықтары мен кемшіліктері бар, бұл олардың арналуымен байланысты.Қарастырылған тәсілдердің бірі - Shared Preferences (Жалпы параметрлер). Бұл әдіс қарапайым деректерді сақтау болып табылады. Shared-prefs "жеке" бағдарлама қалтасындағы XML файлындағы "кілт-мән" түрінде. Shared Preferences boolean, string, float, long, int негізгі түрлерін қолдайды және әдепкі мәндерді, теңшелетін теңшеулерді, кластың айнымалы экземплярын, пайдаланушы интерфейсінің ағымдағы күйін жылдам сақтау үшін қолданылады. Көбінесе пайдаланушы сессиялары арасында деректердің тұрақтылығын қамтамасыз ету үшін пайдаланылады және көптеген бір типті құрылымдалған деректерді сақтау үшін жарамсыз. 


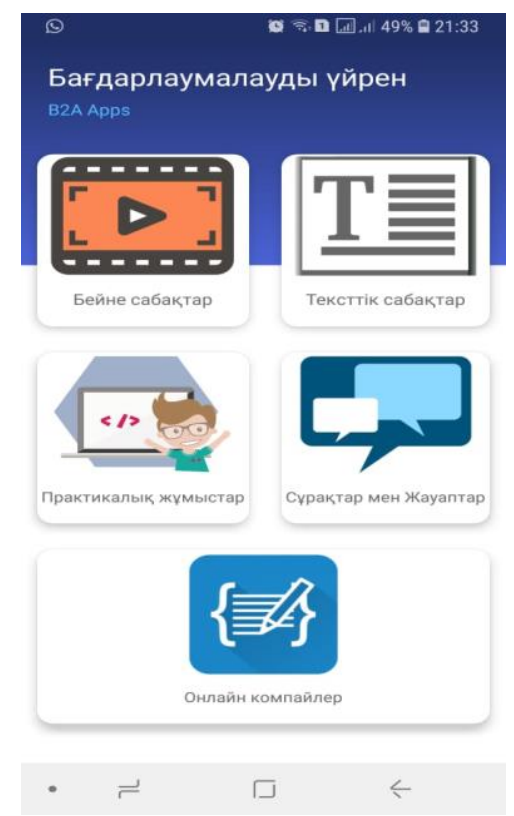

Cурет 1. «B2A Learning» мобильді қ̧осымшасының интерфейсі

Екінші әдіс үлкен көлемді деректерді оқу және жазу үшін басынан аяғына дейін рұқсат етілмеген. Бұл әдіс деректер, медиа және желі арқылы берілетін басқа да файлдар үшін қолайлы.

Үшінші әдіс шартты түрде екіге бөлуге және оларды дұрыс қарастыруға болады. Файлдарды ішкі жадыда сақтау пайдаланушы да, басқа да қолданбалар да өңделетін қосымшалардың файлдарына дейін болмауы тиіс болған кезде жұмыс істеу үшін қолайлы. Ішкі жады әрқашан қол жетімді. Android қолданбасын жойғанда, ішкі жадтан оның барлық файлдарын жояды.

Мобильді қосымша екі негізгі бөліктен тұрады: деректер қоры және программалық компоненттер.

Деректер қоры үш кестеден тұрады: Collections, Words және Users. Collections кестесінде пайдаланушы коллекцияларының тізімі және ол туралы ақпарат сақталады. Word кестесінде сөздер тізімі сақталады, ал Meanings кестесінде осы сөздердің мәндерінің тізімі сақталады. 1-қосымшада кестелер деректерінің толық сипаттамасы берілген.

Мобильді қосымшаның компоненттері

Қосымша архитектурасы Model-View-Presenter жобалау паттернін қолданады. Осы паттерннің негізгі идеясы қосымшаның деректер моделін, пайдаланушы интерфейсін және пайдаланушымен өзара әрекеттесуді компоненттердің біреуінің модификациясы қалғандарына ең аз әсер ететіндей үш жеке компонентке бөлу үшін кілттеледі. Бұл паттерн кластардың 3 негізгі түрінің болуын болжайды:

1) Model - бағдарлама деректерін сақтауға жауап беретін класстар, сондай-ақ осы деректермен жұмыс істеу әдістері;

2) View - қосымшаның интерфейсі үшін жауап беретін класстар. Олар Presenter қабатының кластарымен берілетін деректерді өңдейді, сондай-ақ Presenter қабатының класына басқаруды бере отырып, қолданушының іс-әрекетіне жауап қайтарады (мысалы, түймені басу);

3) Presenter - Model мен View арасындағы байланысты қамтамасыз ететін класстар. Model өзгерістеріне жауап береді, сондай-ақ View қабатының кластарын берген қолданушының іс-әрекетін өңдейді.

Программалық жабдықты тестілеу белгілі бір түрде таңдалған тесттердің соңғы жиынтығында жүзеге асырылатын бағдарламаның нақты және күтілетін мінез-құлқы арасындағы сәйкестікті тексеру [5]. Қосымшаны тестілеу үшін келесі әдістер қолданылды:

- тақырып модульдік тестілеу;

- автоматтандырылған UI-тестілеу;

- функционалдық тестілеу.

Модульдік тестілеу - бұл бағдарламаның жекелеген компоненттерінің дұрыстығын тексеруге мүмкіндік беретін тестілеу түрі

Автоматтандырылған UI тестілеу - жүйенің жұмысын нақты қолданушылардың жұмысын эмулияциялау көмегімен техникалық тапсырмаға сәйкестігін тексеру мақсатында жүргізілетін тестілеу түрі [6]. Тестілеудің осы түрін жүзеге асыру үшін Espresso және JUnit кітапханалары 
пайдаланылды, олар нақты Android құрылғыларында да, эмуляторларда да тесттер өткізуге мүмкіндік береді [7].

Функционалдық тестілеу - бұл функционалдық талаптардың іске асырылуын тексеру мақсатында бағдарламалық қамтамасыз етуді тестілеу, яғни бағдарламалық қамтамасыз етудің белгілі бір жағдайларда қолданушыларға қажетті міндеттерді шешу қабілеті [8]. Функционалдық талаптар бағдарламалық қамтамасыз етуді не істеп жатқанын, ол қандай міндеттерді шешетінін анықтайды. Құрылған қосымша сәйкес тестілеуден өтті.

Жоғарыда сипатталған алгоритм негізінде «В2A Learning» мобильді қосымшасы әзірленді, онда программалау бойынша сабақтар әзірленді, мультимедиалық оқу материалдары, қолданушы білімін тексеруге арналған тест ұсынылды. Мобильді қосымша оқу материалдарын сақтауға және таратуға, оқушылардың білімін бақылау туралы мәліметтерді тіркеуге, мониторинг пен бақылаудың негізгі функцияларын іске асыруға мүмкіндік беред Әзірленген мобильдік қосымшаны эксперименттік апробациялау - оқу процесін ұтқыр қолдауды ақпараттық-технологиялық қамтамасыз етуді пайдалану, білім беру мекемелеріндегі студенттердің үлгерім көрсеткіштерінің жақсаруына әкеп соқтыратынын дәлелдеді, өйткені білім беру процесі туралы деректерді сақтауға, оқу материалдарын сақтауға және таратуға, оқушылардың білімін бақылау туралы мәліметтерді тіркеуге, сондай-ақ оқытудың кемшіліктерін анықтау және білім деңгейінде әлсіз жерлерді талдау сияқты мониторинг пен бақылаудың негізгі функцияларын іске асыруға мүмкіндік береді.

Пайданылван ддебиеттер тізімі:

1 Куляшова Н. М., Карпюк И. А., Дроздов С. А. Основные принщипь построения и классификации информационно-поисковых систем // Материаль ХVI науч. конф. молодых ученых, аспирантов и студентов Мордов. гос. ун-та. им. Н. П. Огарёва: в 6 ч. - Ч. 3. Естественные науки. Саранск, 2013, С. 66-68

2 Пантилейкин Н. В. Мобильные приложения и их виды // Научно-методчческий электронный журнал Кониепт. - 2016. - T. 26. - С. 776-780.

3 Куклев В.А. Сущзостные характеристики мобильного обучения. Известия ВГПУ, 68-стр, 2009.

4 SQLite vs MySQL vs PostgreSQL: Сравнение систем управления базами данных. URL: http://devacademy.ru/posts/sqlite-vs-mysql-vs-postgresql/(om 12.04.2017).

5 Введение в веб-модель MVC Spring. URL:: https://netbeans.org/kb/docs/web/quickstart-webappsspring_ru.html (om 23.04.2019).

6 Шалтабаев А.А., Смагулова Л.А., Теберикова Д.Б. Мобильді құрылвыларва арналван қосымшаларды тестілеу ддістерін талдау. // Абай атындавы ҚазҰПУ Хабаршысы. «Физика-математика» сериясы №2(66), 2019, 285-2906.

7 Caüm Android Studio. URL: https://developer.android.com/studio/features.html (дата обращения: 12.03.2017).

8 Тестирование программного обеспечения - основные понятия $u$ определения. URL: http://www.protesting.ru/testing/ (дата обращения: 16.05.2017).

\section{References:}

1 Kuljashova N. M., Karpjuk I. A., Drozdov S. A. (2013) Osnovnye principy postroenija i klassifikacii informacionno-poiskovyh sistem Materialy XVI nauch. konf. molodyh uchenyh, aspirantov i studentov Mordov. gos. unta. im. N. P. Ogarjova: v 6 ch. Ch. 3. Estestvennye nauki. Saransk, 66-68.

2 Pantilejkin N. V. (2016) Mobil'nye prilozhenija i ih vidy Nauchno-metodicheskij jelektronnyj zhurnal Koncept. 776-780.

3 Kuklev V.A. (2009) Sushhnostnye harakteristiki mobil'nogo obuchenija. Izvestija VGPU, 68.

4 SQLite vs MySQL vs PostgreSQL: Sravnenie sistem upravlenija bazami dannyh. URL: http://devacademy.ru/posts/sqlite-vs-mysql-vs-postgresql (ot 12.04.2017).

5 Vvedenie v veb-model'MVC Spring. URL: https://netbeans.org/kb/docs/web/quickstart-webapps-spring_ru.html (ot 23.04.2019).

6 Shaltabaev A.A., Smagulova L.A., Teberikova D.B. (2019) Mobil'di kurylgylarga arnalgan kosymshalardy testileu adisterin taldau. Abaj atyndagy KazUPU Habarshysy. «Fizika-matematika» serijasy №2(66), 285-290.

7 Sajt Android Studio. URL: https://developer.android.com/studio/features.html (data obrashhenija: 12.03.2017).

8 Testirovanie programmnogo obespechenija - osnovnye ponjatija i opredelenija. URL: http://www.protesting.ru/testing/(data obrashhenija: 16.05.2017). 